SHS Web of Conferences 2, 00009 (2012)

DOI: $10.1051 /$ shsconf $/ 20120200009$

(C) Owned by the authors, published by EDP Sciences, 2012

\title{
Evaluation of the borrower's creditworthiness as an important condition for enhancing the effectiveness of lending operations
}

\author{
A. Chaplinska
}

Daugavpils University, Latvia

\begin{abstract}
In this research, analyzing the difficulties of efficiency of commercial banks' credit operations, the author has paid special attention to such issues like the process of management and assessment of borrowers' creditworthiness, as well as formation of credit portfolio in unsteady conditions of economics. The main risk of formation of commercial bank's credit portfolio is made up of the credit risk. In the present situation in Latvia, when during the pre-crisis years the commercial banks dramatically increase the volumes of their credit portfolios, the basic challenge for them is balance of profitability of credit portfolio and quality. Here, if the mechanisms of the market self-regulation do not function, only efficient supervising system can help. Latvia is one of the first countries of the Eastern Europe, which has a united institution of supervision of financial and capital market being established and having commenced its work, which is also a step into the direction of development, safety and stability of the credit market. Analyzing the formation of the credit portfolio of the Latvian commercial banks in the unsteady economical circumstances, researching the statistical data of the Bank of Latvia and the Financial and Capital Market Commission, the author has made conclusions that during the crisis period both the physical volume of credit portfolios o the Latvian commercial banks and their quality and profitability have decreased, together with rapid increase of the volume of overdue credit payments. In this situation the author would recommend paying special attention to more efficient management of the quality of granted credits without materially decreasing the volume of credit portfolios themselves. In its turn, in order to efficiently manage the quality of granted credits, one has to use the results of the local researches, not relying particularly on the foreign researches, which refer to the conjuncture of other markets, specific nature of other economics and other time.
\end{abstract}

Key words: loan, borrower, creditworthiness, creditor, bank

Credit ensures the continuity of ongoing economic activity of businesses, enables businesses to carry out operational activities without violation of a payment circle. Banks should have a complete understanding of all aspects of financial economic activity of enterprises in order to enhance and strengthen the customer base.

In modern conditions the risk of loan default is particularly high because of many factors. The actual financial position of some enterprises could not be considered creditworthy. However, working in market environment is unthinkable and not effective without raising funds to cover the needs for financial resources. Many enterprises regardless of their ownership form are based on limited capital which does not allow them to sell their work on the basis of their capital, which in its turn creates the need to overtake credit resources and use them. In the process of conducting a credit strategy at the level of a specific borrower it is important for a bank to determine its credibility. The need to justify the economic methods of managing credit operations focused on the economic boundaries of the credit comes to the fore. It will allow avoiding credit exposures, which are not effective from the point of view of money circulation, to ensure the timely and full repayment of loans, which is essential to improve the utilization of material and financial resources.

Lack of theoretical and methodological maturity of these issues necessitates the creation of a mechanism and methods for quantitative and qualitative creditworthiness assessment of enterprises, for

This is an Open Access article distributed under the terms of the Creative Commons Attribution License 2.0, which permits unrestricted use, distribution, and reproduction in any medium, provided the original work is properly cited. 


\section{SHS Web of Conferences}

stability analysis of commercial organizations, predicting the effects of exposure to internal and external factors. The task of the article is to touch upon some aspects of the problem on the example of the credit market in Latvia during the recession.

\section{Materials and methods}

The theoretical and methodological base of the research is the works of the foreign and the Latvian scientists in the classical theory of finances, crediting theory, as well as other fields of banking activities, which reflect theory and methodology of different crediting process aspects; legislative and institutional instruments, which refer to the crediting activity of commercial banks; various scientific concepts of credit and borrower's creditworthiness, as well as other materials, which refer to the role of the commercial banks and borrowers and difficulties in crediting process. To achieve the research aim the experts' publications have been also used about the quantitative and qualitative factors of financial condition of the company. The Latvian national legislative acts, normative documents, experts' acknowledgments, the analytical reports of the Latvian economists and other documents regulating the bank activity in Latvia were used within the course of the research.

Within the course of implementation of the research the official statistics of activity of commercial banks of Latvia of the Bank of Latvia (LB), the Association of Latvian Commercial Banks (LKA) and the Financial and Capital Market Commission (FKTK), as well as Lursoft data about the financial ratios of the borrowers was used. Solving the objectives set forward, general scientific methods of research of economical and financial phenomena, method of analysis and synthesis, as well as statistical information analysis were applied.

\section{Results and discussion}

An important tool for analysis and decision-making is credit scoring. Algorithms used in credit scoring system allow classifying borrowers according to the degree of creditworthiness, grouping them into classes with different credit ratings on the basis of the information concerning only borrowers themselves. But in such a case the quality of previously received loan services, macroeconomic conditions at the moment of delivery as well as the ability to change these conditions at the time of the loan due to external influences are not taken into consideration. Quality of loan service by specific borrowers can greatly depend on changes of macroeconomic situation. Their migration from one class of reliability to another is also possible. This is due to the fact that external factors such as abrupt changes in energy prices, exchange rates, changing terms of taxation and interest rates may have a direct impact on the financial condition of enterprises. The consequences of these factors for different types of enterprises- borrowers may be different due to different capabilities to adapt to external influences. These opportunities may depend on industry sector, technology, management, etc. So to assess the impact of external factors on the different types of borrowers, as well as on the credit market as a whole (an increase in the number of problematic borrowers, the growth of accounts payable in the banking system, etc.) it is necessary to use adequate econometric model of indicator dependence for certain types of borrowers (credit rating) of recent individual and macroeconomic indicators (financial indicators and the quality of servicing the debt).

Three parties bear responsibility of credit activity - the borrower, the lender, the state. The main requirements of a number of regulatory documents - the "Law of Credit Institutions" of Latvia, the Financial and Capital Market Commission (hereinafter referred to as FKTK) - "Regulation of Credit Risk Management", FKTK "Rules of evaluation off-balance sheet assets and liabilities", FKTK "Rules of restricting the permissible concentration of risk in banking transactions" and others are directly or indirectly related to the definition of creditworthiness of a borrower.

The year 2009 is notable for the largest number (more than ten) of institutional arrangements associated with the measures taken in the process of lending. As a result, by the end of 200913 Latvian 
Int. Conf. SOCIETY. HEALTH. WELFARE; Congr. of Rehabilitation Doctors of Latvia

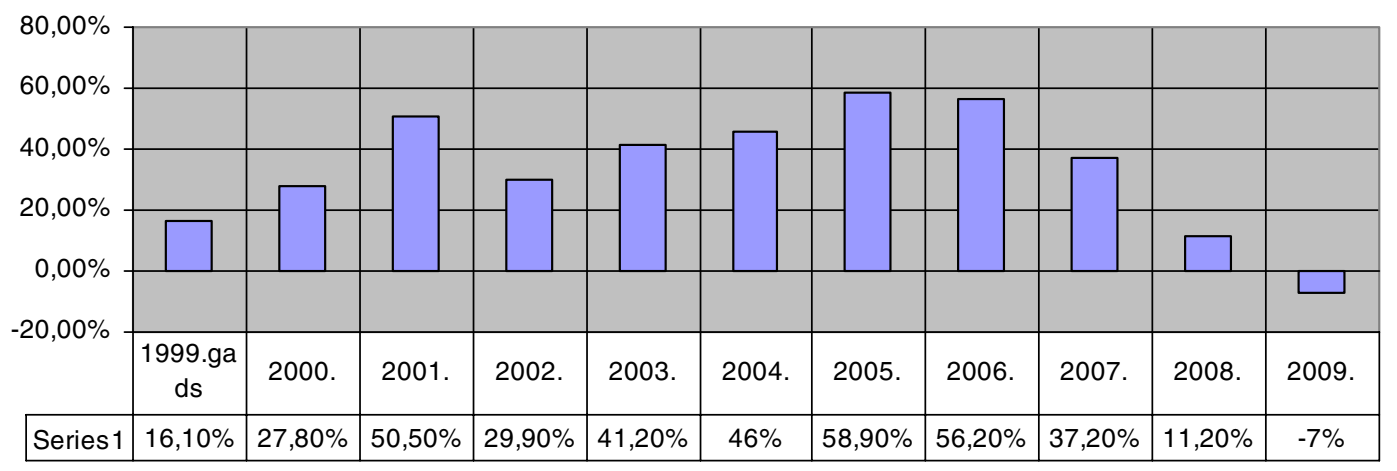

Figure 1. Dynamics of the credit portfolio of the Latvian commercial banks (\% as compared with the previous year).

Source: author's summarized and calculated data from the Bank of Latvia (hereinafter referred to as the LB) and the statistics of the Financial and Capital Market Commission (hereinafter referred to as the FKTK).

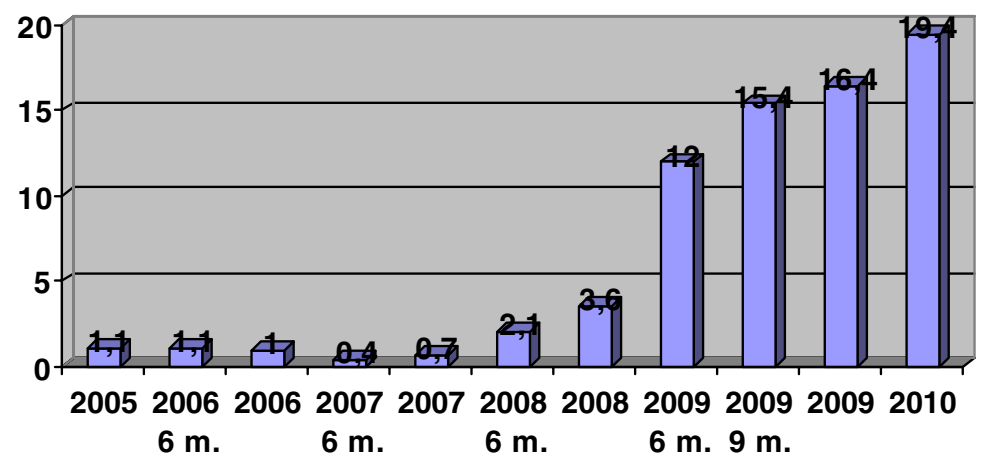

Figure 2. Loans overdue by 90 days (\% of credit portfolio).

Source: FKTK statistics (Finanšu un kapitāla tirgus komisijas statistika).

banks had additional capital increase by almost one billion lats (912 ml. lats). From April 2010 new demands of FKTK concerning monitoring, analyzing additional information on problem loans came into force. The need for strict control on the part of supervisory institutions is dictated by the rapid growth of loan portfolio in Latvian banks in recent years (1999-2008) (in some banks loans amounted to $75-82 \%$ of assets (Čevers, Karnīte, 2006; 59). As well as the "quality" received in the race interbank competition.

In 2009 the total volume of credits issued by commercial banks had reached 15,4 milliard lats (hereinafter LVL), in comparison with the credit portfolio of 1999 with 0,85 milliard LVL. The maximum volume of credit portfolio was reached in 2008 - 16,6 milliard LVL, i.e., if comparing with 1999 the portfolio has grown 20 times; it experienced the most active growth in five years from 2003 till 2007, when the volume of credit portfolio of the Latvian banks grew at the average each year by $37 \%-59 \%$. Exactly after Latvia entered the EU in 2004 two years of credit portfolio growing the most rapid followed (annual growth in relation to the previous year reached almost $60 \%$ (see Figure 2).

Even despite the worsening of economical situation and decrease of availability of credit resources the volumes of crediting went on growing, only in 2009 the credit portfolio started to slowly amortize and to the end of the year it decreased by $7 \%$.

The credit portfolio growth was stimulated both by the fact that the national economy of Latvia had completely overcome the consequences of the Russian economical crisis in 1998, and the entrance of 


\section{SHS Web of Conferences}

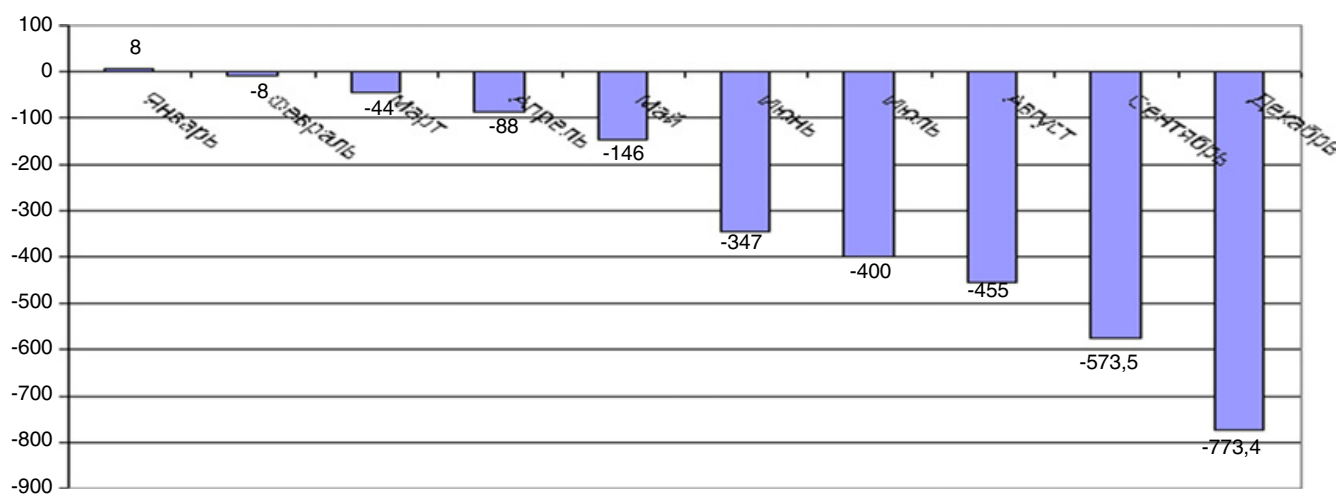

Figure 3. Banking losses in 2009 (in millions of lats at the end of each month). Source: FKTK statistics (Finanšu un kapitāla tirgus komisijas statistika).

Latvia in the European Union (EU), and the growth of money demand, by stabilization and improvement of macroeconomic environment. The commercial banks system development can also be mentioned as the factor of the credit portfolio growth; the number of creditworthy companies grew, gradual decrease of credit rates took place. The year of 1999 is considered to be the year of stabilization of the Latvian financial system.

The research of lending trends, conducted among 9 major banks by Bank of Latvia (the holders of more than $85 \%$ of the total credit portfolio) in the first half of 2009 confirmed the tightening of credit standards applied for credit assessment (Finanšu un kapitāla tirgus komisijas statistika). Therefore, bank credit availability has become more cautious, because in this economic situation the assessment of creditworthiness of borrowers hampers their opportunity to qualify for new credit obligations. The scepticism, concerning the creditworthiness of potential borrowers is further enhanced by the insolvency dynamics of enterprises. For comparison, 1092 of insolvency applications for the 9 months in 2008 to 1959 for the 9 months in 2009. In general, a quarter of loans in Latvia (including 28,000 private individuals) had problems with creditworthiness. The share of borrowers who were behind on debt payment by more than 90 days increased dramatically. According to Bank of Latvia, in 2009, the number of such borrowers in the overall credit portfolio increased 5 times compared with the previous year, so far as the year 2007 was concerned this number increased more than 20 times.

The quality of loan portfolio is directly dependent on creditworthiness of a borrower. In 2009, the banking sector of Latvia had sharp increase in losses, if at the beginning, of the year banks worked with profits, starting with February till the end of year financial losses gradually grew and the end of the year they increased more than 96 times amounting to 773.4 million lats (see Figure 3). Compared to the previous year the profit of the banking sector was 213.4 million lats, but in 2007 the profit amounted to 371 million lats. Banks tried to improve the situation through restructuring and renewal of existing loans. Over half a year in 2009 restructured loans amounted to more than one billion lats. Thus, active credit activity in recent years, and insufficient assessment of the creditworthiness of a borrower has passed to the uncertainty, what the resulting losses of credit will be, and who will take the greatest share of the losses.

In such situation banks do not wish anymore to take risk by easy issue of credits, which request from banks a different solution that is the most suitable for each customer.

The commercial banks form current reserves for unsafe credits in the external regulation system of credit portfolio risk of commercial banks of the Latvian supervising institutions, basing on their classification into 5 quality groups.

A specific credit is included into the specific group by formal features - planned payments' overdue or commencement of legally fixed events - each quarter during a year. 
Int. Conf. SOCIETY. HEALTH. WELFARE; Congr. of Rehabilitation Doctors of Latvia

Table 1. Classification of reserves of commercial banks for unsafe credits.

\begin{tabular}{|l|c|}
\hline Quality groups & Risk level and reservation norm, \% \\
\hline$\bullet$ standard loans (credits) & 0 \\
\hline$\bullet$ loans under standard & 10 \\
\hline$\bullet$ loans under supervision & 30 \\
\hline$\bullet$ problem loans & 60 \\
\hline$\bullet$ lost loans & 100 \\
\hline
\end{tabular}

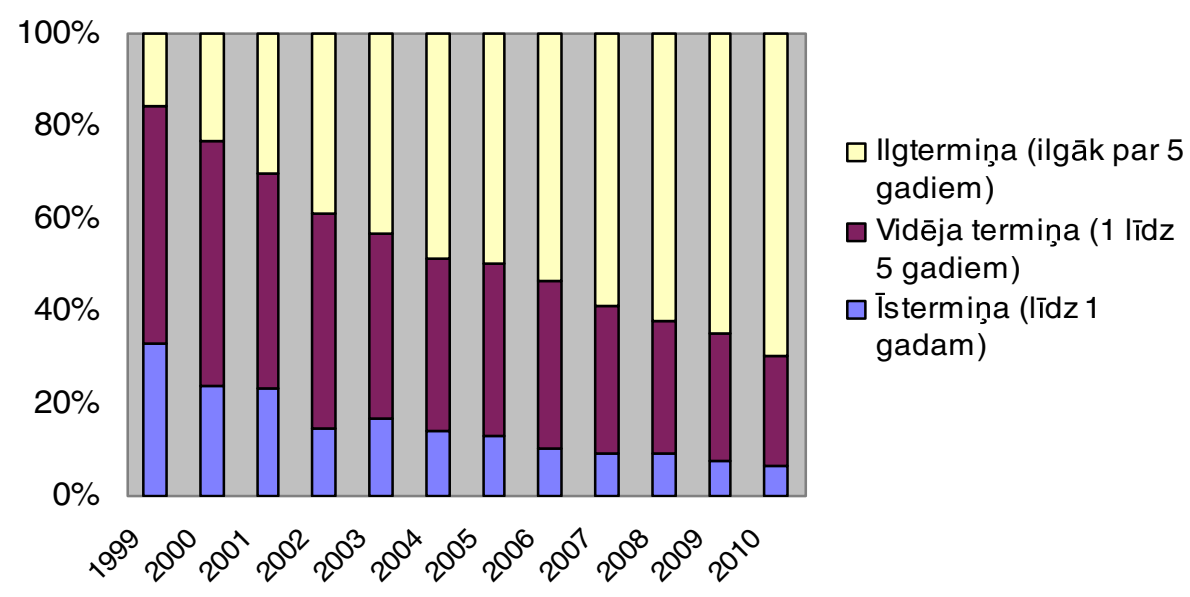

Figure 4. Fixed-date structure of loans issued by the Latvian commercial banks in 1999-2010, in the end of the period, in percent.

Source: author's summarized data from LB and FKTK statistics.

Banks delay much deeper situation worsening by restructuring and prolonging the current credits. In the first half a year of 2009 restructuring was performed and the term for credits was prolonged or postponed with a total amount of approximately 1,1 milliard LVL.

Those credit takers who have made payment delays for more than 60 days and if the payment sum is not less than $100 \mathrm{LVL}$, its equivalent in foreign currencies will be included, by the initiative of the Bank of Latvia, in the Debtor Register created on October 1, 2003. Thus, with the help of the Debtor Register banks receive information about the customers who, avoiding debt instruments in one bank search for possibility to receive credit in other bank.

Since January 1, 2008 the Credit Register has started its work - database about liabilities of all borrowers against the participants of the financial market of Latvia, who are members of the Credit Register. In such a full spectrum the Debtor Register Database has been also integrated in the Credit Register (established since the middle of 2003), which will be supplemented in the future also by the information about negative credit history, including, the overdue payment. One has to add that such registers function in the most part of the states of the EU.

Some experts think and the author agreed to those that in a wider sense all society is interested in the credit register existence (Smane, 2008). This is an information system, which summarizes, accrues in a centralized way and stores information about borrowers and their liabilities. At first, the information available to the register members give opportunity to more precisely assess the creditworthiness of the borrower and plan his own credit policy. It is especially topical right now when the banks in Latvia observe stricter credit policy - they will be able to learn in the credit register whether the credit applicant has liabilities in any other bank or other financial institution.

Until now it was impossible to obtain summarized information anywhere. When such information is received banks can evaluate whether the customer will be able to return the borrowed means and offer him corresponding loan agreement provisions. In order to attract bigger number of customers 


\section{SHS Web of Conferences}

and increase the market shares, banks often took large risk, insufficiently critically evaluating the customers' creditworthiness. Credits play great role in economics, because they materially increase the purchasing capacity, which leads to the inflation growth. Without additional financing it is impossible to have economical growth and thus crediting is necessary. The most important thing is to assign bigger role to the quality of issued credits and decrease risk. Until recent crediting tempo rapidly grew in the society, there were optimistic views reigning in it. Credits became more available thanks to great competition among banks - banks were taking additional means in holding banks or, if there were no such possibility, they were taking credit in the EU banks, as well as lowered the interest rates. Now the country experiences high inflation; the real estate field has obvious crisis, businessmen feel more and more difficulties, and the export is weakened and private persons start suffering from inflation and credit load. Banks issue less credits, there are more bad credits, customers use different services less, and as a result of this the banks' profit decreases. However, when a united credit register is formed, and the banks try to more seriously research the customers' creditworthiness, as well as the fact that the government performs actions to improve the situation, there us grounds to hope that this all will "soften" the crisis, which, unfortunately, is unavoidable due to insufficiently longsighted activities.

\section{Conclusions}

Creditworthiness of borrowers continued to deteriorate. Lending is "on the brake" - the demand has reduced, a critical approach on the part of borrowers, the proposal by the banks is very cautious - a sceptical approach to the creditworthiness of the borrower. In 2009 FKTK made a record number of institutional decisions and actions to correct the situation, monitoring and control, but nevertheless, the results the performance of borrowers and lenders (banks) analyzed in the article do not convinced that the measures were taken in a timely manner.

The relationship between the economy and banks resemble a vicious circle, banks can not assess the creditworthiness of potential borrowers by traditional methods, for fear of financial loss of an existing loan portfolio, as the economy is not stable. In turn, the economy does not stabilize, feeling the credit crunch. Banks suffered increasing losses and lost the desire to lend. One of the prerequisites for an active credit activity - updating the methods for assessing creditworthiness correct recognition of the dependence between the analyzed indices using adequate econometric models, can significantly improve the accuracy of decisions.

\section{References}

Čevers, M., Karnīte, R. (2006) Nerezidentu noguldījumi Latvijas bankās. Rīga: Latvijas Zinātņu akadēmijas Ekonomikas institūts, 89 lpp.

Šīrenbeks, H. (1998) Modernais banku kontrolings. Rīga: Zinātne, 147. -135. lpp.

Zelgalve, E. (2004) Kredītspējas analīze un novērtēšana. Rīga: LU Ekonomikas un vadības fakultāte. Kutuzova, O. (2001) Finanses un kredīts. Rīga: Turība, 40. lpp.

Rose, P.S. (2002) Comercial Bank Managment - USA: MeGrow-Hill Company Inc, p. 528.

Latvijas bankas Interneta mājas lapa. www. bank. $1 \mathrm{v}$.

Finanšu un kapitāla tirgus komisijas statistika. www.fktk. lv. 